\title{
Development of the Vocational Colleges in the Construction of Service Education System
}

\author{
Zhou Weiping \\ Ningbo City College of Vocational Technology \\ Ningbo, Zhejiang, China \\ Yuan Sufang \\ Ningbo City College of Vocational Technology \\ Ningbo, Zhejiang, China
}

\author{
Ren Guocan* \\ Ningbo City College of Vocational Technology \\ Ningbo, Zhejiang, China \\ renguocan@nbcc.cn \\ *Corresponding author
}

\begin{abstract}
From the orientation and participation of the vocational colleges in the construction of the service education system, the author analyzes how the colleges should participate in the service of the local economic development, points out the bottleneck which blocks the way of vocational colleges participation of the construction of the service education system, and probes into the talents training mode of college-enterprise cooperation. It is concluded that a social service system of mutual help between the colleges and enterprises be set up, which needs a triple-interaction system of talents training among the colleges, enterprises and the government. Meanwhile, the connotation of the service education of the vocational colleges should be innovative so as to seek better ways of development.
\end{abstract}

Keywords-service; the education system; higher vocational colleges; the development train of thought

\section{INTRODUCTION}

In recent years, along with the changes in the macroeconomic environment at home and abroad, is an urgent need to speed up transformation of the pattern of economic development in our country, the economic and social development to rely on scientific and technological progress, improve quality of the labor force, transformation of management innovation. Ningbo, as one of the most developed city in China, along with the readjustment of industrial structure under the system of economic globalization and the growing of China's rural economy, the consumption structure, such as changing the upgrading of the industrial structure is faced with enormous pressure, issued by the municipal government in August 2005, 《about to speed up the constructing service-oriented education system, strengthen the education service ability of economy and society several opinions》, issued in October 2008 《about deepening the service-oriented education system to speed up the cultivation of the several opinions of the high-quality practical talents $》$, to build a service-oriented education system of strategic decision, is proposed to build more perfect applied talents training system, establishing the smooth operation of university-industry cooperation system, perfect the system of various forms of education and training services and further promote the independent innovation, vigorously implement the "two hit" double industrial projects and services leapfrog development, strengthen the Ningbo support sustained and rapid economic and social coordinated development of talents, to speed up cultivating applied talents with high quality.

\section{THE CONNOTATION OF THE SERVICE-ORIENTED EDUCATION SYSTEM}

"Put forward by the Ningbo city building adapted to the local economic and social development, and industrial development phase, reasonable structure, type, diverse, flexible mechanism, the dynamic service-oriented education system" [1], is the government to deepen education reform, improve the education service is an important measure of economic and social ability. Service-oriented education system is one of the economic and social service as the core, the new system for the development of education, in service is a new concept of regional education development.

\section{THE Higher Vocational COLleges IN THE} SERVICE-ORIENTED EDUCATION SYSTEM THE LOCATION IN THE BUILDING AND THE STATUS QUO

\section{A. In the Building of a Service-oriented Education System In Higher Vocational Colleges}

As the mainstay of service-oriented education system construction in higher vocational colleges and the leader, must play its own specialty, talent and technology advantages, fully engaged in a service-oriented education system construction, service for the transformation and development of the regional economy, improve the supporting capacity of higher education to economic and social talents, knowledge, ability and service ability. School-running orientation for its development direction of higher vocational colleges, the school-running idea, the construction strategy plays an important role in guiding, the school's top design. Under the architecture of service-oriented education system, higher vocational colleges as a place, to give full consideration to the regional economic and social development demand for higher vocational talents, breaks through the traditional education mode, adjust specialties, and comprehensively improve the ability and level of running the platform and the carrier, realize rapid and sustained development of the school. 
B. Of the Current Situation of Higher Vocational Colleges to Participate in A service-oriented Education System to Build

In recent years, in the process of building a service-oriented education system, higher vocational colleges in talents cultivation idea, talent training mechanism, the personnel training mode and characteristic of the very big change happened in such aspects as talent cultivation path.

1) The formation of service-oriented concept of talent training. Service-oriented concept of talent cultivation is a positive, active and pragmatic attitude, in the face of the economic society of college talent cultivation put forward higher requirements, formed a kind of social demand oriented, is characterized by practical education, economic and social comprehensive initiative service theory [2]. Higher vocational colleges initiative to society, to the enterprise, and gradually form the social demand oriented, characterized by useful education, initiative service idea of cultivating talents in economic and social, the development of the school philosophy realize transition from passive adaptive into active service.

2) The marketization of the talent training mechanism gradually improve. The school-running pattern in higher vocational colleges not only achieve the change from a closed mode into an open mode, at the same time in the school level gradually change from academic education to lifelong education. The higher vocational colleges by conducting ordering cultivation, the succession of the engineering, project cooperation in running schools, carried out the interactive between colleges training mode reform. At the same time, higher vocational colleges use their talent and technology advantage, the enterprise research center moved to the school, help enterprise product development, design, develop, and solve the technical problem, gradually improve the service-oriented education system under the market mechanism of talents training.

3) The running mechanism of university-enterprise cooperation basic establishment. In recent years, the city has more than 500 companies and local colleges and universities set up a partnership, education and economic society linkage development mechanism has been formed. Companies are directly involved in the colleges and universities, professional construction, the design professional talent training scheme, arrange students to practice, build the laboratory or engineering research center, and to form a joint research team has carried out in-depth cooperation.

4) The applied talent cultivation system preliminary formation. With the construction of a service-oriented education system, preliminary perfect applied talents cultivation system. Ningbo 10 applied talents cultivation base and 16 service key specialty construction in full swing, participate in the specialized construction of nearly 50 , more than hundreds of cooperation, basic covers the city's leading industries and emerging industries, strengthen the education and training services.

\section{Restricting the Construction of Higher Vocational Colleges and Universities Deeply Involved in a Service-oriented Education System Bottlenecks}

The construction of a service-oriented education system have on the development of local higher vocational colleges in Ningbo has a substantial change, from a service-oriented education idea, talent training mechanism, running mechanism and so on have achieved certain results, "but overall, the zhuhai education with social and economic linkage development mechanism is not perfect enough, the amount of applied talents, the structure and quality also cannot fully adapt to the needs of economic and social development" [3].

1) The higher vocational college of the existing personnel training mode can't meet the applied talents for the regional economic development. The current higher vocational talents training mode to cultivate applied talents no matter from the quantity, professional structure and comprehensive quality can fully meet the needs of the economic and social development.

2) The research direction of higher vocational colleges combine with the local industry development closely degree is not high. Higher vocational colleges at present, the research overall level is low, the research direction of scattered, not bind to Ningbo regional industry development and ability to solve practical problems for the enterprise needs to improve.

3) The specialty construction in higher vocational colleges to dock with the effective regional economic development. Higher vocational colleges because of its history, teacher, professional construction of characteristic is not obvious, or distinctive but with the characteristics of regional economic development is not unified, not harmonious, not very good service for the regional economic development.

4) The social training of vocational colleges system can't satisfy the business enterprise the urgent demand for talent. The rapid development of Ningbo economy, demand for talent and enterprise staff's quality, quantity, strong and urgent, college social training system is still cannot meet the demand of the enterprise. Intensify vocational education and staff training, strive to cultivate high-quality practical talents, for local economic and social development to provide a more powerful safeguard factors of talent.

\section{Higher Vocational COlleges IN THE BUILDING OF A SERVICE-ORIENTED EDUCATION SYSTEM DEVELOPMENT}

In the process of building a service-oriented education system, higher vocational colleges should give full play to their professional advantage, we will focus on developing high quality and high skill talented person's raise, application development, skill training and innovation of enterprise's technical service work, to establish a professional as the carrier, the important way for production-study-research cooperation, realize the applied talents cultivation and industry technology innovation platform for the society. 
A. To the Local Economy Needs as the Breakthrough Point,

Deepen the Cooperation Between Colleges Training Mode

In higher vocational colleges should combine the development of local economic development needs, according to the requirement of regional economic development, "timely tracking the change of market demand, adapt to the needs of economic and social development of region, industry, according to the school conditions, targeted adjustment and setting up the professional" [4], focus on cultivating high-quality skilled talents for the development of regional economy.

\section{B. To Enterprise Technology Research as the Leading}

Direction of Scientific Research in Higher Educational

Institutions, Establish a Mutual Assistance between

Higher Vocational Colleges and Social Service

Mechanism

Social service is an important form of higher vocational colleges broaden the development way, the teacher should become the backbone of the enterprise of science and technology research and development, technology promotion, in order to further do a good job in the construction of a service-oriented education system schools to cooperate with local government deepened, innovating the mechanism of university-enterprise cooperation, improve the ability of higher vocational colleges, realize the local economic industrial chain and the interactive development mechanism of school professional chain. Do university-enterprise cooperation to declare research projects, construction of research center, the total set of scientific research team, sharing equipment resources, make the school in the traditional industry upgrade technology, emerging industries play an important role in the innovation of scientific research; Schools should also make full use of existing resources, and enterprises to carry out the qualification education, staff training, skill evaluation, etc, for the industry, enterprise services, in the process of social services, improve the teachers' scientific research level; At the same time, through in-depth cooperation with industries and enterprises, schools, organize students to participate in projects such as scientific research, innovation, improve the students' ability of innovation, entrepreneurship, improve the students' employment competitiveness.

\section{At Cultivating Talents Cultivation Base and}

Service-oriented Education Key Specialty Construction as

the Carrier, the Formation of "Schools, Enterprises and

Government" Tripartite Linkage Mechanism of Talents

Training

Ningbo specialty construction in higher vocational colleges to strengthen the pertinence, provide personnel and intellectual support for Ningbo's economic and social development, improve the quality of higher education and the school level, Ningbo set up 10 applied professional talents cultivation base construction projects and 16 key construction professional service oriented education, higher vocational colleges make full use of the two carriers, fully prepared two articles of higher education and social service. Through JiaoJiao related, sharing between teachers, curriculum and experimental facilities, between between the construction of laboratory, practical teaching base, carry out and a series of measures -- order-form train together, gradually formed for the purpose of serving local economy, highly skilled personnel training as the core, schools, enterprises and government "linkage" tripartite, with distinct regional characteristics of applied talents training mechanism.

\section{To Participate in National Higher Vocational Education Reform Pilot Area Construction as an Opportunity to Service-oriented Education Connotation of Innovation in Higher Vocational Colleges}

At present, higher vocational education through the system and mechanism innovation, Ningbo has made great progress, but compared with the economic and social needs, educational level remains to be improved, the service of economic and social ability remains to be further strengthened. According to the state council general office of the notice of the pilot implementation of the national education system reform, Ningbo become a local government to promote the development of higher vocational education comprehensive reform pilot area, higher vocational colleges must firmly seize this favorable opportunity, in a service-oriented education system on the connotation of innovation.

1) For breakthrough in system and mechanism innovation. Further deepen the reform of the personnel training mode, deepen the construction of the mechanism of production. In the cultivation of high quality applied talents pay attention to openness and cooperation, emphasis on the use of social resources, the introduction of the main body of enterprises and all aspects of the educational pattern.

2) To seek innovation on crack development problem. According to the industry development direction of Ningbo, the original in performance assessment of construction projects, and straighten out the school specialized construction and the corresponding relationship of regional industry development directly, the mismatch between the school development, and form a reasonable space layout, and professional structure adapted to the local industrial structure, enhance the connotation of school.

3) On the promotion development space for expansion. Through the service economy society development space, running school in higher vocational colleges in Ningbo service industry applied talents' with high skill training base, social training service base, and the window of foreign exchange and cooperation, promote higher vocational education in Ningbo health, coordinated and sustainable development.

\section{REFERENCE}

[1] Ningbo 《about to speed up the building a service-oriented education system to enhance the ability of serving local economic and social several opinions》》 [Z]. Ningbo ZhengFa [2005] no. 74.

[2] Hu Chidi, 《Under double pressures of the service personnel training mode of refactoring $\rangle[\mathrm{J}]$. Journal of higher education research. 2009 (2).

[3] Ningbo 《about deepening the service-oriented education system to speed up cultivating high-quality applied talents of several opinions $\rangle[\mathrm{Z}]$. Ningbo ZhengFa [2008] no. 86. 
[4] The ministry of education 《about comprehensive several opinions on improving the quality of higher vocational education teaching $\rangle[\mathrm{Z}]$. Teach high [2006] no. 16. 